\title{
Hoffa's Disease in Elderly Patients
}

\author{
Rabia TERZi' ${ }^{1}$, Tülay ÖZER² \\ ${ }^{1}$ Clinic of Physical Medicine and Rehabilitation, Derince Training and Research Hospital, Kocaeli, Turkey \\ ${ }^{2}$ Clinic of Radiology, Derince Training and Research Hospital, Kocaeli, Turkey
}

Hoffa's disease was first defined as an acute or chronic inflammation of the infrapatellar fat pad by Albert Hoffa in 1904 (1). It is also known as the infrapatellar fat pad syndrome, liposinovitis prepatellaris, syndrome of the infrapatellar fat pad impingement, and hoffitis $(2,3)$. It is a rare cause of anterior knee pain (4). Although the etiology of the disease is unclear, it is believed that recurrent extension traumas of the knee have a role (5). In this study, Hoffa's disease that developed without any risk factor and that demonstrated healing with conservative treatment in a geriatric patient has been presented along with a discussion in accordance with literature.

An 88-year-old female patient presented to our clinic with a complaint of pain and swelling in the anterior region of the right knee, which had been gradually increasing for 6 months. She had no history of any trauma or surgery. Her pain increased with movement. Her physical examination revealed genu recurvatum deformity in both the knees. Pain was detected in the anterior region of the right knee joint, and there was a moderate level of movement restriction in the joint. In particular, during the extension movement of the knee, an increase in the level of pain was observed. Minimal effusion in the right knee, swelling in the infrapatellar region, and tenderness on applying pressure were found. The patient was evaluated to be positive by Hoffa's test. McMurray and Apley's and ligament stability tests were negative. The value of visual analog scale (VAS) was found to be $6 \mathrm{~cm}$ during rest and $9 \mathrm{~cm}$ during movement. In functional assessment, Lysholm score was 43. In addition, in laboratory examination, erythrocyte sedimentation rate was $36 \mathrm{~mm} / \mathrm{h}$, C-reactive protein level was $3.46 \mathrm{mg} / \mathrm{L}$, and rheumatoid factor was negative.
The roentgenogram of the right knee revealed several ossifying formations that did not cause any erosion in the adjacent bone cortex and placed on the localization of the lateral infrapatellar fat pad, independent from bone structures, and it also demonstrated moderate degree of osteoarthritis (Figure 1). In magnetic resonance imaging (MRI) of the knee, ossifying structures were apparently hypointense in the infrapatellar fat pad in the direct graph in sagittal T1-weighted images. In oil-based sagittal T2-weighted MRI image, they were hypointense in an inhomogeneous internal structure, causing minimal expansion in fat tissue (Figure 2). No soft tissue with different intensity was available in the fat tissue around ossifying formations. The patient was diagnosed with Hoffa's disease on the basis of the existing clinical and radiological findings. She was informed about her disease and treatment alternatives. During the treatment, cold compression and rest were applied to the right knee. Transcutaneous electrical nerve stimulation, isometric quadriceps exercises, and $15 \mathrm{mg}$ meloxicam $(1 \times 1)$ were implemented. On the $15^{\text {th }}$ day of the treatment, VAS pain score was found to be $3 \mathrm{~cm}$ during movement and Lysholm score was evaluated as 65 .

The infrapatellar fat pad is a highly sensitive and wellvascularized structure in the anterior region of the knee, in which the nerve endings and neural networks are intense (6, 7). Along with supporting the biomechanics of the knee, it has a role in chondrocyte modulation through IL-6, TNF- $\alpha$, VEGF, and $\beta$-FGF productions (8). It is considered that the disease occurs when the infrapatellar fat pad is inflamed after being squeezed between the patella and femoral condyles because of recurring traumas. Hoffa's disease is mostly observed in young

Address for Correspondence: Rabia Terzi, MD, Derince Eğitim ve Araştırma Hastanesi, Fiziksel Tıp ve Rehabilitasyon Kliniği, Kocaeli, Türkiye.

Phone: +905053515572 E-mail: drrabia1@yahoo.com

Received: August 2014 Accepted: December 2014

OCopyright 2015 by Turkish Society of Physical Medicine and Rehabilitation - Available online at www.ftrdergisi.com Cite this article as: 


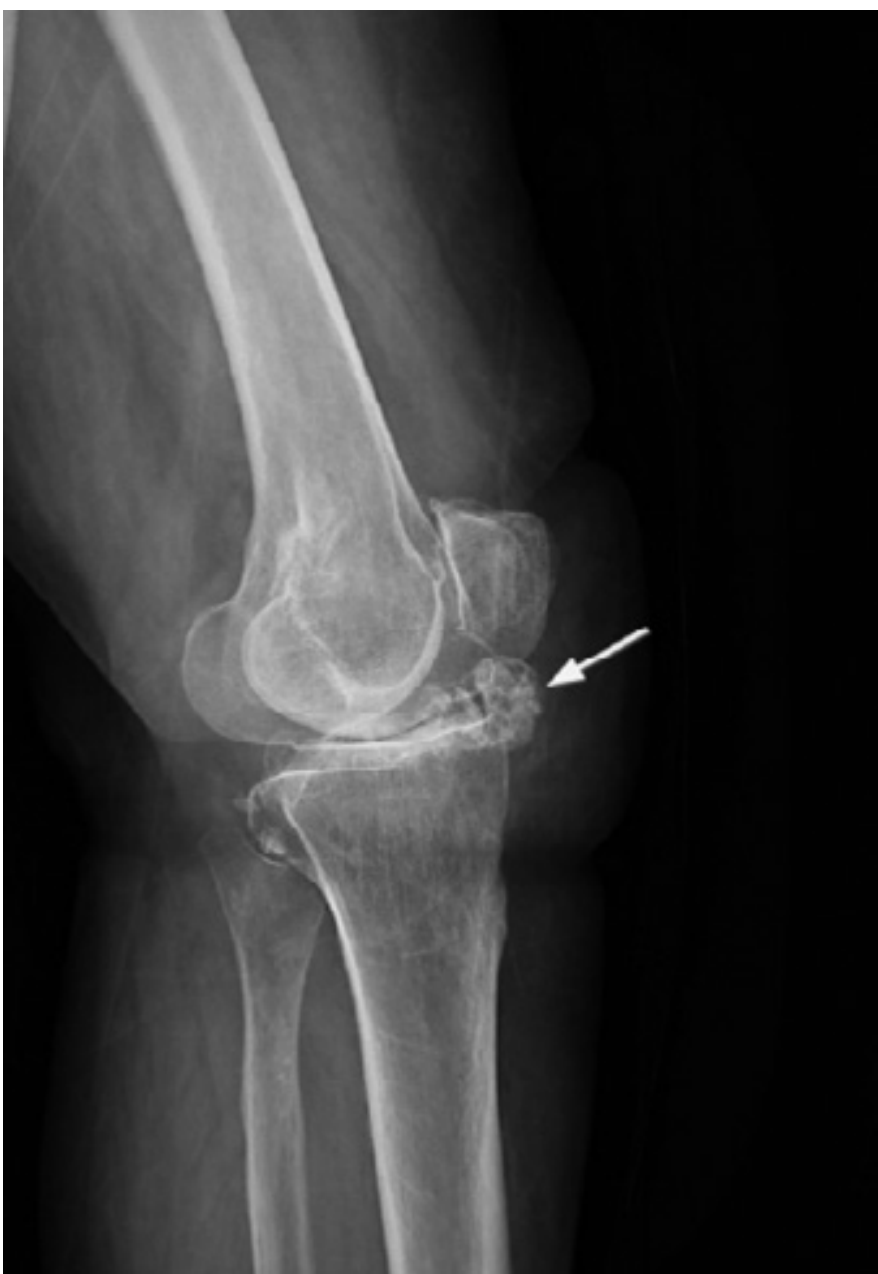

Figure 1. Osseous mass in the infrapatellar region in lateral radiography
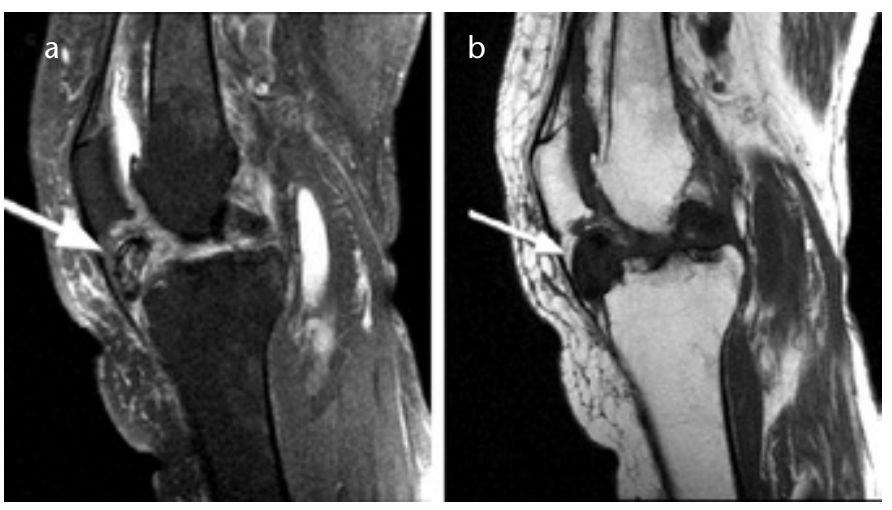

Figure 2. a, b. In the infrapatellar fat pad, (a) a sagittal

T2-weighted MRI image with apparent hypointense lesion and

(b) a sagittal T1-weighted MRI image with hypointense lesion causing mild expansion in inhomogeneous fat tissue

women and in individuals involved in sports, such as basketball and volleyball, that include jumping movements (5). Arthritis, synovitis, patellofemoral joint dysplasia, tumoral structures, and scar tissue or arthrofibrosis, which have surgically or traumatically occurred, are other conditions that lead to inflammation in the fat pad of Hoffa (9-11). The absence of a history of a trauma and previous surgery and other risk factors in our patient is remarkable. Similar to our case, Park et al. (12) presented Hoffa's disease that developed without any trauma in an elderly patient. In the histopathological examination of a biopsy specimen, they detected mucoid degeneration, and they stated that fat pad degeneration could also be a cause of Hoffa's disease (12). No histopathological examination was performed for our patient. However, it was considered that ligamentous instability, which might be associated with existent genu recurvatum deformity, might have established a ground for Hoffa's disease in our patient.

In the manifestation of Hoffa's disease, pain and swelling increasing with overload or the movement of the knee in the infrapatellar or retropatellar tendon region, functional impairment imitating ligament injury, massive effusion or recurrent hydrarthrosis episodes, joint weakness, and subpatellar discomfort are observed (3). The definition of our patient's pain in the anterior region of the knee, the pain increasing during extension, and a positive Hoffa's test result suggested that clinical findings developed because of Hoffa's disease.

Because Hoffa's fat pad includes residual synovium, primary neoplastic diseases of the synovium can originate from this area. In this respect, differential diagnosis is of vital importance. Osteochondroma, nodular synovitis, fibroma, synovial sarcoma, and pigmented villonodular synovitis are pathologies that should be considered in differential diagnosis (12). Moreover, it has been reported that Hoffa's disease may be associated with the development of ossifying chondroma (5). While radiographs are valuable, particularly in the ossifying stages of Hoffa's disease (5), inflammation, swelling, hypertrophy, fibrosis, calcification, and other lesions in the infrapatellar fat pad can easily be diagnosed through MRI (13). Therefore, MRI evaluation was preferred for the differential diagnosis in our patient. Because the MRI did not reveal granulation around the bony structures mostly observed in the case of osteochondromas or an increase in the signal intensity of the chondroid matrix, osteochondroma was not considered.

In conservative treatment, cold compression, non-steroid anti-inflammatory drugs, banding applications, local steroid and anesthetic administration, physical therapy agents, quadriceps and vastus medialis strengthening exercises, and surgical interventions, including partial resection, are recommended $(5,9,13)$. Our patient had ossifying Hoffa's disease at chronic stage. Despite this, remarkable healing of her pain was obtained with conservative treatment.

Although Hoffa's disease is mostly observed in young individuals, it can develop in the elderly. It is a pathology that should be considered for patients with complaints of pain and swelling in the anterior region of the knee. Healing of pain and improvement in the functional state can be obtained with the administration of conservative treatment alternatives and physiotherapy practices. 
Peer-review: Externally peer-reviewed.

Author Contributions: Concept - R.T.; Design - R.T.; Supervision - R.T., T.Ö.; Resource - R.T.; Materials - R.T.; Data Collection and/or Processing - R.T.; Analysis and/or Interpretation - R.T., T.Ö.; Literature Review - R.T.; Writer - R.T.; Critical Review - R.T., T.Ö.; Other - R.T., T.Ö.

Conflict of Interest: No conflict of interest was declared by the authors.

Financial Disclosure: The authors declared that this study has received no financial support.

\section{References}

1. Hoffa A. The influence of adipose tissue with regard to the pathology of the knee joint. JAMA 1904;43:325-8. [CrossRef]

2. Bohnsack $M$, Hurschler $C$, Demirtas $T$, Rühmann $O$, StukenborgColsman C, Wirth CJ. Infrapatellar fat pad pressure and volume changes of the anterior compartment during knee motion: possible clinical consequences to the anterior knee pain syndrome. Knee Surg Sports Traumatol Arthrosc 2005;13:135-41. [CrossRef]

3. Emad Y, Ragab Y. Liposynovitis prepatellaris in athletic runner (Hoffa's syndrome): case report and review of the literature. Clin Rheumatol 2007;26:1201-3. [CrossRef]

4. Sivrioglu AK, Ozyurek S, Incedayi M, Mutlu H. A rarely diagnosed cause of anterior knee pain: Hoffa's disease. BMJ Case Rep 2013;2013.
5. Larbi A, Cyteval C, Hamoui M, Dallaudiere B, Zarqane H, Viala $P_{1}$ et al. Hoffa's disease: a report on 5 cases. Diagn Interv Imaging 2014;95:1079-84. [CrossRef]

6. Kennedy JC, Alexander IJ, Hayes KC. Nerve supply of the human knee and its functional importance. Am J Sports Med 1982;10:329. 35. [CrossRef]

7. Krenn V, Hofmann S, Engel A. First description of mechanoreceptors in the corpus adiposum infrapatellare of man. Acta Anat (Basel) 1990;137:187-8. [CrossRef]

8. Ushiyama T, Chano T, Inoue K, Matsusue Y. Cytokine production in the infrapatellar fat pad: another source of cytokines in knee synovial fluids. Ann Rheum Dis 2003;62:108-12. [CrossRef]

9. Duri ZA, Aichroth PM, Dowd G. The fat pad. Clinical observations. Am J Knee Surg 1996;9:55-66.

10. Magi M, Branca A, Bucca C, Langerame V. Hoffa disease. Ital J Orthop Traumatol 1991;17:211-6.

11. Steadman JR, Dragoo JL, Hines SL, Briggs KK. Arthroscopic release for symptomatic scarring of the anterior interval of the knee. Am J Sports Med 2008;36:1763-9. [CrossRef]

12. Park JH, Park JH, Lee AH, Lee DH. An unusual presentation of Hoffa's disease in an elderly patient with no trauma history: a case report. Acta Orthop Traumatol Turc 2011;45:195-9. [CrossRef]

13. von Engelhardt LV, Tokmakidis E, Lahner M, Dàvid A, Haage P, Bouillon B, et al. Hoffa's fat pad impingement treated arthroscopically: related findings on preoperative MRI in a case series of 62 patients. Arch Orthop Trauma Surg 2010;130:1041-51. [CrossRef] 